\title{
The Non-neuronal Cholinergic System of Human Skin
}

\author{
Authors \\ H. Kurzen ${ }^{1}$, I. Wessler ${ }^{2}$, C. J. Kirkpatrick ${ }^{2}$, K. Kawashima ${ }^{3}$, S. A. Grando ${ }^{4}$ \\ Affiliations \\ Department of Dermatology, University Medical Center Mannheim, University of Heidelberg, Heidelberg, Germany \\ Institute of Pathology, Johannes Gutenberg-University, Mainz, Germany \\ Department of Pharmacology, Kyoritsu College of Pharmacy, Tokyo, Japan \\ Department of Dermatology, University of California Davis, Sacramento, USA
}

Key words

- acetylcholine

choline

endocrine

immune system

angiogenesis

received 22.12.2005

accepted 16.3.2006

Bibiliography

DOI 10.1055/s-2007-961816

Horm Metab Res 2007; 39:

125-135

(c) Georg Thieme Verlag KG

Stuttgart · New York .

ISSN 0018-5043

Correspondence

\section{H. Kurzen}

Department of Dermatology . Venereology and Allergology. University Medical Center Mannheim · Ruprecht-Karls University of Heidelberg · TheodorKutzer-Ufer 1-3.68135 Mannheim. Germany

Tel.: +49/621/3832280

Fax: +49/621/383 3815

Hjalmar.Kurzen@haut.

ma.uni-heidelberg.de; Hjalmar.

Kurzen@nexgo.de

\section{Abstract \\ $\nabla$}

In human skin both resident and transiently residing cells are part of the extra- or non-neuronal cholinergic system, creating a highly complex and interconnected cosmos in which acetylcholine $(\mathrm{ACh})$ and choline are the natural ligands of nicotinic and muscarinic receptors with regulatory function in both physiology and pathophysiology. ACh is produced in keratinocytes, endothelial cells and most notably in immune competent cells invading the skin at sites of

\section{Introduction}

Numerous studies performed in recent years have firmly established the human skin as not only a target but also an active source of various neurotransmitters and hormones. The extra- or non-neuronal adrenergic and cholinergic systems have begun to attract increasing attention as regulators of skin physiology and pathophysiology [1-4].

In 1921 Otto Loewi and Henry Dale identified acetylcholine $(\mathrm{ACh})$ as a principal neurotransmitter, a discovery that was rewarded with the Nobel prize for physiology and medicine in 1936. In the following years, most advances were made by the description of ACh action in the central nervous system and by the characterization of its nicotinic (nAChR) and muscarinic (mAChR) receptors [5]. ACh is synthesized from choline and coenzyme A by choline acetyltransferase (ChAT), which is the rate-limiting step in ACh de novo synthesis and it is degraded by acetylcholinesterase (AChE). The first hint towards a nonneuronal production of ACh in the skin came in 1983 from studies on salivary glands of rats, which continued to produce large amounts of ACh despite prior denervation [6]. Six years later ACh production was found in blood cells of rab- inflammation. The cholinergic system is involved in basic functions of the skin through autocrine, paracrine, and endocrine mechanisms, like keratinocyte proliferation, differentiation, adhesion and migration, epidermal barrier formation, pigment-, sweat- and sebum production, blood circulation, angiogenesis, and a variety of immune reactions. The pathophysiological consequences of this complex cholinergic "concert" are only beginning to be understood. The present review aims at providing insight into basic mechanisms of this highly complex system.

bits [7] and today, ACh production and expression of its receptors have been shown in a wide variety of organisms from protozoa and plants to humans, thus supporting the hypothesis that ACh is a universal cytotransmitter which has only secondarily become specialized in the nervous system. In humans, different tegumental cells covering the inner and outer surfaces of the human body and most notably various immune cells are part of the non-neuronal cholinergic system [8].

The non-neuronal cholinergic system has been implicated in numerous functions in the skin such as growth and differentiation, adhesion and motility, barrier formation, sweat and sebum secretion as well as modulation of the microcirculation. An important role in human disease, especially in inflammatory disorders such as acne vulgaris or atopic eczema is emerging together with a wealth of new data on its physiological role in maintaining skin homeostasis $[4,9]$. In human skin both resident and transiently residing cells are part of this system, creating a highly complex and interconnected cosmos in which ACh is the main player with regulatory roles in both physiology and pathophysiology [10]. The aim of this review is to provide insights into basic mechanisms of ACh action 
Table 1 AChR selectivity of cholinergic ligands (modified from Alexander et al. [121, 122])

\begin{tabular}{|c|c|c|c|c|}
\hline & \multicolumn{2}{|c|}{ Nomenclature } & \multirow{2}{*}{$\begin{array}{l}\text { Agonists } \\
\text { ACh, CCh }\end{array}$} & \multirow[t]{2}{*}{ Antagonists } \\
\hline $\mathrm{nAChR}$ & & subunits & & \\
\hline \multirow[t]{5}{*}{ Heterooligomers } & $\alpha 1^{*}$ & $\alpha \beta \delta \varepsilon$ & ACh, CCh, Epi & $\alpha$ Btx, Tub, Str, Suc, Dec Hex \\
\hline & $\alpha 3^{*}$ & $\alpha 3 \beta 2 \pm \alpha 5$ & Epi $>$ Nic $>$ ACh & $\kappa \mathrm{Btx}>\mathrm{Hex}, \mathrm{CtxMII}>\mathrm{Mec}>$ Tub $>$ Atrop \\
\hline & & $\alpha 3 \beta 4 \pm \alpha 5$ & Epi $>$ Cyt $=\mathrm{Nic}>\mathrm{ACh}$ & $\kappa$ Btx, Hex CtxAulB $>$ Mec $>$ Tub \\
\hline & $\alpha 4^{*}$ & $\alpha 4(\beta 2 \mid \beta 4) \pm \alpha 5$ & Epi $>$ Cyt $=$ Sub & $\mathrm{D} \beta \mathrm{E}>\mathrm{Tub}>\mathrm{Mec}$ \\
\hline & $\alpha 10 \alpha 9$ & $\alpha 10 \alpha 9$ & ACh & $\alpha$ Btx $>$ Str Atrop, Nic, Mus \\
\hline \multirow[t]{2}{*}{ Homooligomers } & $\alpha 7^{*}$ & $\alpha 7_{5}$ & Cho $>$ Nic & $\mathrm{KyA}>\alpha \mathrm{Btx}>\mathrm{Str}$ \\
\hline & $\alpha 9^{*}$ & $\alpha 9_{5}$ & Cho $>$ ACh & $\alpha$ Btx $>$ Str, Atrop, Nic, Mus \\
\hline \multirow[t]{6}{*}{$\mathrm{mAChR}$} & & & ACh, CCh, Mus, Met & Atrop, Scop \\
\hline & $\mathrm{M}_{1}$ & & AC-42, Des & Gly (11), MT7 (9.8), 4-DAMP (9.2) Trip (8.8), Pzp (8.5) \\
\hline & $\mathrm{M}_{2}$ & & $\mathrm{BCh}$ & Trip (9.4), AFDX384 (9.0), Hmn (8.3), 4-DAMP (8.4), Pzp (6.7) \\
\hline & $M_{3}$ & & Cho, L-689 & $\begin{array}{l}\text { Gly (11), 4-DAMP (9.3), Dar (8.9), Hmn (6.4), Tio (kinetic } \\
\text { selectivity), }\end{array}$ \\
\hline & $\mathrm{M}_{4}$ & & McN-A343 & 4-DAMP (9.4), Hmn (8.8), MT3 (8.7), Pzp (8.1), $\operatorname{Dar}(8.0)$ \\
\hline & $M_{5}$ & & Mus > ACh & 4-DAMP (9.0), Dar (8.1), Pzp (7.1) \\
\hline
\end{tabular}

ACh: acetylcholine; Atrop: atropine, BCh: bethanechol; $\alpha$ Btx: $\alpha$-bungarotoxin; $\kappa$ Btx, $\kappa$-bungarotoxin; CCh: carbachol; Cho: choline, Ctx: $\alpha$-conotoxin; Cyt: cytisine; Dar: darifenacine; Dec: decamethonium; D $\beta$ E: dihidro- $\beta$-erythroidine; Des: desmethylclozapine; Epi: epibatidine; Gly: glycopyrrolate; Hex: hexamethonium; Hmn: himbacine; KyA: kynurenic acid; Mec: mecamylamine; Mus: muscarine; Met: metacholine; MT3 and MT7: mamba toxins 3 and 7; Nic: nicotine; Pil: pilocarpine; Pzp: pirenzepine; Scop: scopolamine; Sub: suberyldicholine; Suc: succinylcholine; Str: strychnine; Tio: tiotropium: Tub: d-tubocurarine. Values in parantheses denote antagonist apparent affinities (pKB). Glycopyrrolate selectivity according to Haddad et al. [123]. Kinetic selectivity of tiotropium at the $\mathrm{M}_{3}$ according to Disse et al. [115]. A convincing subtype selectivity for muscarinic agonists has so far not been established.

and shed light into possible interconnections of the different components of the non-neuronal cholinergic system of the skin.

\section{Pharmacology of AChR \\ $\nabla$}

Hitherto, five molecular subtypes of muscarinic $A C h R, M_{1}-M_{5}$, have been identified. These receptors are single subunit transmembrane glycoproteins of which the $\mathrm{M}_{2}$ and $\mathrm{M}_{4}$ are coupled to G-proteins of the $\mathrm{G}_{\mathrm{i}}$ family, leading to inhibition of cAMP synthesis. The $\mathrm{M}_{1}, \mathrm{M}_{3}$ and $\mathrm{M}_{5}$ subtypes are coupled to the $\mathrm{Gq}$ class of the G-proteins acting on down- stream signals such as phospholipase $\mathrm{C}$ or $\mathrm{D}$, consequently regulating intracellular calcium levels [11].

Human nicotinic nAChR are composed of different subunits, i.e. $\alpha 1-\alpha 10, \beta 1-\beta 4, \gamma, \delta$ and $\varepsilon$, which can be combined to pharmacologically distinct pentameric ion channels. The $\alpha 1, \beta 1$ and $\delta$ chains form heteropentamers present at the neuromuscular junction together with the $\gamma$ (fetal phenotype), and $\varepsilon$ (adult phenotype) chains. The neuronal heteropentamers that contain the $\alpha 3$ subunit together with other subunits are also termed $\alpha 3^{*}$ nAChR. The $\alpha 7$ and $\alpha 9$ subunits form homopentamers and are mainly gating calcium while the $\alpha 3^{*}$ nAChR are sodium and/or potassium channels [12]. It has been suggested that $\alpha 9$ subunits may form heteromeric nAChR together with $\alpha 10$ subunits [13]. Depending on their subunit composition, the nAChR show different affinities for $\mathrm{ACh}$, choline and other cholinergic compounds like nicotine. Both $\mathrm{ACh}$ and choline have been shown to activate the $\mathrm{M}_{3} \mathrm{AChR}$ while all other $\mathrm{mAChR}$ are physiologically activated only by ACh [14]. Of the nAChR, the $\alpha 7$ and $\alpha 9$ homopentamers are activated by choline, but not the $\alpha 3^{*}$ nAChR (Table 1). In the past, the question of agonist or antagonist AChR subtype selectivity has contributed considerably to confusion in $\mathrm{AChR}$ research. For example, atropine has been viewed as a classical antimuscarinergic substance. Recent studies, however, have demonstrated that nAChRs are also inhibited by atropine, in the rank order $\alpha 9>\alpha 7>\alpha 3$ nAChR $[15,16]$. The $\alpha 9 / \alpha 10$-nAChRs behave pharmacologically distinct and can be activated neither by nicotine nor muscarine. These classical cholinergic agonists reduce the ACh effects at the $\alpha 9-\mathrm{nAChR}$. Like the $\alpha 7-\mathrm{nAChR}$, the $\alpha 9 / \alpha 10-n A C h R s$ can be blocked by $\alpha$-bungarotoxin and like the mAChR they can be blocked by atropine. Similar to the AChR present at the neuromuscular junction ( $\alpha \beta \delta \varepsilon-\mathrm{nAChR})$ they can be blocked by strychnine $[1,17-20]$. In addition, along with their classical orthosteric binding site for ACh and competetive antagonists, mAChRs possess a second, allosteric binding site. Allosteric binding modulates the action of ligands at the orthosteric binding site. This process is designated positive or negative cooperativity. Gallamine is one of the first substances with proven negative cooperativity at the mAChRs. Strychnine, a potent inhibitor of glycine receptors and of the $\alpha 1$ and $\alpha 9 \mathrm{nAChRs,}$ has been shown to exert positive cooperativity with $\mathrm{N}$-scopolamine (a competitive $m A C h R$ inhibitor) at the $\mathrm{M}_{2}$ and $\mathrm{M}_{4} \mathrm{AChRs}$ and a negative cooperativity with $\mathrm{ACh}$ at the $\mathrm{M}_{2}$ and $\mathrm{M}_{3}$ AChRs [21]. In addition, strychnine has also been shown to activate at least the $\mathrm{M}_{2}$ and $\mathrm{M}_{4}$ AChRs at the allosteric binding site independent of natural ligands [22]. This complex binding and activation pattern that can be found for several cholinergic substances and explains different effects of the same substance on the same cells, dependent on the presence or absence of natural or synthetic agonists and antagonists [21-23]. Because of the described highly complex actions and interactions of cholinergic substances, older pharmacological studies have to be interpreted cautiously. Using antimuscarinergic substances, it has to be kept in mind that the so called "selective" binding is lost, if higher concentrations of the respective antagonist are applied. Recent studies using antisense oligonucleotides or siRNA approaches have tried to circumvent these difficulties $[24,25]$. The different pharmacological properties of commonly used cholinergic agonists and antagonists are summarized in Table 1.

\section{Is endocrine action of ACh mediated via choline? $\nabla$}

In the body, choline serves several biological functions. It is the precursor of phosphatidylcholine and sphingomyelin, two phos- 
pholipids that serve as components of biological membranes and as precursors for intracellular messengers such as diacylglycerol or ceramide. Choline is also the precursor of ACh and two signaling lipids, platelet-activating factor and sphingosylphosphorylcholine. Furthermore, choline can be enzymatically degraded to betaine and $\mathrm{H}_{2} \mathrm{O}_{2}$ via choline oxidase. The methyl groups of betaine may then used to resynthesize methionine from homocysteine, thereby providing methionine for protein synthesis and transmethylation reactions [4,26]. Activation of AChRs through choline provides the basis for an endocrine action, while ACh itself is degraded rapidly through AChE, thus acting only in an autocrine or paracrine manner. Choline, usually as part of phosphatidylcholine, is widely available in a number of foods. Dietary intake of choline ranges from 300 to $900 \mathrm{mg}$ a day and the mean serum free choline level is $\sim 35 \mu \mathrm{M}$ at birth and gradually decreases to $\sim 10 \mu \mathrm{M}$ after birth [27]. Choline fits the original description of a vitamin and is classified today as an essential nutrient [26]. In many mammals, long term (weeks to months) ingestion of a diet deficient in choline is adequate, however, when limited to methionine and folate leads to hepatic, renal, pancreatic, memory, and growth disorders. Muscle damage also occurs from choline deficiency $[28,29]$.

Mammalian cells in culture require choline for cell division and without it die by apoptosis. Apoptosis-induction via choline deficiency has also been observed in liver epithelial cells where it is associated with cell-cycle arrest and upregulation of p53 and $\mathrm{p} 21^{\mathrm{WAF} 1 / \mathrm{CIP} 1}$ as well as with persistent activation of NF- $\kappa \mathrm{B}$. This interesting finding has been interpreted as a possible molecular mechanism by which choline deficiency may promote carcinogenesis [30]. Hypercholinemia has been found to indicate a poor prognosis in patients with acute coronary syndrome. The source of choline whole blood elevation has not been determined and needs further research [31]. Probably because of the hitherto underestimated endocrine action of choline on AChR present in the different non-neuronal cholinergic systems, there are no reports on the effects of choline deficiency or choline excess on skin physiology or the immune system. It has been recently demonstrated that choline is chemotactic to human epidermal keratinocytes [24], and that its downstream signaling of keratinocyte $\alpha 7$ AChR, which involves the Ras/Raf-1/MEK1/ ERK pathway coupled to integrin expression, mediates cholinergic regulation of keratinocyte directional migration [24]. It remains to be determined which sources are mainly responsible for choline present in blood and tissues in different physiological and pathological situations and whether variations in choline concentration indeed influence signaling of the different nonneuronal cholinergic systems.

\section{Impact of ACh on keratinocyte biology}

$\nabla$

As for other kinds of tegumental cells, resident skin cells like keratinocytes synthesize and degrade ACh [32]. While the $\alpha 2, \alpha 4$, $\alpha 6, \beta 3 \mathrm{nAChRs}$ have never been demonstrated in human skin, several studies have identified the presence of $\alpha 3, \alpha 5, \alpha 7, \alpha 9, \alpha 10$, $\beta 2$ and $\beta 4 \mathrm{nAChR}$. In addition, the presence of $\beta 1 \mathrm{nAChR}$ mRNA and protein was shown only recently $[9,18,20,33$,$] . There seems$ to be a highly variable expression of the $\mathrm{nAChR}$ in the epidermis, especially of the heterooligomeric species of the $\alpha 3^{*}$-type. Putative influencing factors include age, atopic disposition, smoking habits or minimal trauma. Differences in body site may also explain contrasting results obtained with the same antibodies (e.g. anti- $\alpha 3,-\beta 2$ ) by different authors. Based on in situ hybridization and double-label immunofluorescence, the $\alpha 3, \alpha 5, \beta 2$ and $\beta 4 \mathrm{nAChR}$ subunits have been demonstrated in the epidermal basal layer and - to a variable extent - in a single cell layer in the stratum granulosum. The homo-oligomeric nAChR subunits $\alpha 7$ and $\alpha 9$ show a clearly distinct distribution within the epidermis. While the $\alpha 9$ AChR are prominent in the basal layer and lowest suprabasal layers, the $\alpha 7$ AChR can be found in the upper stratum spinosum and in the stratum granulosum, co-localizing with the $\alpha 10$ and $\beta 1$ chain. It is unclear at present whether the $\beta 1$ chain, alone or together with other subunits, can form a functional AChR receptor in the epidermis. The $\alpha 9$ and $\alpha 10$ subunits form functional AChRs in various organs $[13,34]$. However, in the epidermis $\alpha 10$ expression parallels $\alpha 7$ and $\beta 1$ expression rather than $\alpha 9$ nAChR subunit expression. In the other compartments of the skin, there is a complete dissociation of the expression patterns for these four subunits (i.e. $\alpha 7, \alpha 9, \alpha 10$ and $\beta 1$ ), indicating that either $\alpha 10$ might be able to form functional receptors with different subunits, or that $\alpha 10$ like $\beta 1$ might be able to form functional receptors on its own. However, this has never been demonstrated in vitro. Of the $m A C h R, M_{1}$ and $M_{4}$ were found in the suprabasal layers, while $\mathrm{M}_{2}, \mathrm{M}_{3}$ and $\mathrm{M}_{5}$ remained restricted to the lower layers $[9,18,35]$.

The functional impact of the observed AChR distribution in the epidermis has been examined in a current study [36] using organotypic co-cultures (OTC) as an in vitro skin equivalent system. In this system, blocking of all AChR by combined treatment with mecamylamine and atropine or treatment with strychnine (which blocks $\alpha 9$ nAChR) for 7-14 days resulted in complete inhibition of epidermal differentiation and proliferation. Blockage of $\mathrm{nAChR}$ with mecamylamine led to a less pronounced delay in epidermal differentiation and proliferation than blockage of muscarinic $\mathrm{mAChR}$ with atropine, evidenced by reduced epithelial thickness and expression of terminal differentiation markers such as CK2e, CK10 or ZO1. In OTCs treated with atropine, mecamylamine or strychnine there was an intracellular lipid accumulation already in the lower epidermal layers, indicating metabolic stress and a severely disturbed epidermal barrier. In addition, prominent acantholysis could be observed in the basal and lower suprabasal layers in mecamylamine-, atropine- and strychnine-treated cultures, accompanied by a decreased expression of desmosomal, adherens junction and tight junction proteins. This globally reduced cell adhesion led to cell death via intrinsic activation of apoptosis. In contrast, stimulation of $\mathrm{nAChR}>\mathrm{mAChR}$ with cholinergic drugs resulted in a significantly thickened epithelium, accompanied by an increase of intercellular lipid content in the corneal layer. In this study, it was demonstrated that ACh is crucial for the development of a stratified epidermis-like epithelium in vitro, well in line with the fact that virtually all keratinocyte culture media contain choline in a micromolar range [37], corresponding to human free choline serum levels and protecting keratinocytes from apoptosis as described above. Adding the pharmacological profile for the cholinergic substances used to the distribution of the AChR in the epidermis and OTC of different developmental stages, it is most likely that inhibition of either $\alpha 3^{*}$ or $\alpha 9 \mathrm{nAChR}$, which are both expressed in the basal and lower suprabasal layers, is necessary to induce acantholysis. In addition, inhibition of at least the stimulatory $M_{3} A C h R$, possibly also the $M_{5} A C h R$, which are both found in the basal layer, seems to produce similar effects. On the other hand, predominant inhibition of the $M_{1}$ AChR by glycopyrrolate did not lead to acantholysis but to a disturbed 
epithelial architecture in the upper epidermal layers, thus interfering with barrier formation. These conclusions are supported by recent findings using knock-out and gene-silencing approaches [38]. In conclusion, terminal differentiation, barrier formation, keratinocyte cell adhesion and proliferation are controlled by both nicotinic and muscarinic AChR.

\section{Does ACh influence the function of cutaneous adnexal structures? \\ $\nabla$}

The pilosebaceous unit seems to possess a complex AChR expression pattern that is only beginning to be understood. In the infundibulum, an epidermis-like AChR expression pattern has been demonstrated, with increased immunoreactivity especially for the $\alpha 5, \alpha 10, \beta 2, \mathrm{M}_{3}$ and $\mathrm{M}_{5}$ antisera applied. In the subinfundibular outer root sheath, all AChRs except $\alpha 9, \beta 1$ and $\mathrm{M}_{4}$ can be found in the basal layer while the $\alpha 9, M_{4}$ and $M_{5}$ AChRs seem to be restricted to the central layer. The $\alpha 5, \alpha 10, \beta 1, \beta 2, \mathrm{M}_{1}-\mathrm{M}_{4}$ chains are strongly expressed in the inner root sheath. In the trichocytes forming the hair shaft a strong immunoreactivity of $\alpha 3, \beta 4, \alpha 9, \mathrm{M}_{2}, \mathrm{M}_{3}, \mathrm{M}_{4}$ and $\mathrm{M}_{5}$ sera can been noted, while matrix cells seem to express only the $\alpha 5, \alpha 9, M_{3}$ and $M_{4}$ AChR subunits. Up to now, no functional data are available on the impact of ACh on hair follicle biology.

The main manifestation of a reduced sebum production, sebostasis, is dryness of the skin. Increased sebum production, seborrhea, is associated with several skin diseases including acne vulgaris or seborrhoic eczema [39]. Increased sebum production or altered sebum composition may be caused by chronic nicotine exposure on $\mathrm{nAChR}$ present in sebaceous glands explaining why smoking negatively influences acne vulgaris [40]. In sebaceous glands, the undifferentiated basal sebocytes express the $\alpha 3, \alpha 9, \beta 4, \mathrm{M}_{3}-\mathrm{M}_{5}$ AChRs while the $\alpha 7, \beta 2, \beta 4, \mathrm{M}_{2}$ and $\mathrm{M}_{4} \mathrm{AChR}$ subunits are produced in mature sebocytes. The sebaceous duct shows a particularly strong staining with $\alpha 5, \alpha 7$ and $\mathrm{M}_{3}$ sera. The presence of the nAChR suggests a role for ACh in sebum production and as promoter of sebocyte differentiation. Moreover, an upregulation of the "inhibitory" $\mathrm{mAChR} \mathrm{M}_{2}$ and $\mathrm{M}_{4}$ in mature sebocytes as compared to undifferentiated sebocytes of the basal seboglandular layers was demonstrated while the "stimulatory" $\mathrm{mAChR} \mathrm{M}_{3}$ and $\mathrm{M}_{5}$ are both expressed in basal sebocytes [9].

\section{Cholinergic control of melanocytes and tegumental pigmentation \\ $\nabla$}

The roles of melanocytes and endothelial cells in the production of erythema and tanning, respectively, are well-known. Much less is known about the signaling pathways initiating these responses. In certain plants, prokaryotes and eukaryotes, light modulates ACh metabolism, and ACh mediates biologic effects of light on the organism $[41,42]$. Melanocytes (MC) have been shown to be targets of ACh action by virtue of their AChR expression. Both mAChR (M1-M5) and $\alpha 1, \alpha 3, \alpha 5, \alpha 7, \beta 1, \beta 2, \gamma$ and $\delta$ $\mathrm{nAChR}$ have been found in cultured and/or normal human MCs [43]. To characterize the second messenger pathways downstream of the melanocyte $\mathrm{ACh}$ receptors, $\left[\mathrm{Ca}^{2+}\right]_{\mathrm{i}}$ measurements were performed using Fura 2 [43]. Stimulation of MCs with micromolar concentrations of carbachol or muscarine induced a peak of $\left[\mathrm{Ca}^{2+}\right]_{i}$ in MCs, reaching approximately 10 times the baseline at $100 \mu \mathrm{M}$ of muscarine. The rise of $\left[\mathrm{Ca}^{2+}\right]_{\mathrm{i}}$ could be blocked with atropine but not with mecamylamine, suggesting that a ganglionic nAChR subtype was not involved. Regulation of $\left[\mathrm{Ca}^{2+}\right]_{i}$ through melanocyte $\mathrm{ACh}$ receptors suggests an important physiologic role of the ACh axis in melanocyte biology and skin pigmentation. Indeed, in cultures of human MCs, ACh increases the quantity of $\mathrm{Bcl}-2$ and other cell proteins and decreases tyrosine hydroxylase and DOPA oxidase activities [44].

At the skin level, ACh inhibits the local response of MCs to $\alpha$ MSH [45], and directly alters vital functions of MCs. Acting through its nicotinic receptors, ACh has been shown to elicit pigmentation. Melanin pigmentation was the predominant finding in oral mucosal lesions at the site of application for 3-6 months of a sublingual tablet containing $2 \mathrm{mg}$ nicotine in a smoking cessation study [46]. The nicotinic effects of ACh, leading to hyperpigmentation, seem to be controlled by its muscarinic effects, mediated by mAChRs. Kurzen and Schallreuter [4] have recently proposed that the melanocyte M2 and M4 subtypes, which are known to inhibit cAMP synthesis, produce a negative feedback on tyrosinase-pigmentation to counteract the $\alpha-\mathrm{MSH} / \mathrm{MC}-1 \mathrm{R}$ and catecholamine/ $\beta 2$-adrenergic response in MCs as described by Gillbro and co-workers [47].

\section{Hypothetical role of acetylcholine in mediating cutaneous effects of UV radiation (UVR) $\nabla$}

Endogenous NO is generated in human skin in response to both ACh injection and UVR [48], but the cell type producing NO remains unknown. The neural system apparently is not involved since the erythema response to UVB is seen in denervated skin [49]. UVB upregulates NO production in cultured keratinocytes [50] and NO produced by UV-irradiated keratinocytes stimulates melanogenesis. Both UVB- and ACh-induced NO production is mediated by upregulation of the $\mathrm{Ca}^{2+}$-dependent constitutive NO synthase $[48,51]$. ACh is well known to regulate cutaneous blood flow via NO [52]. Therefore, it can be hypothesized that ACh releases NO from keratinocytes and cutaneous endothelial cells, and this NO then induces erythema and melanogenesis, as proposed in 0 Fig. 1.

\section{Vitiligo}

$\nabla$

The response of MCs to ACh depends on the activity/amount of the ACh-degrading enzyme AChE. The AChE activity is lowered in vitiliginous skin during depigmentation, but returns to normal on repigmentation [53], in keeping with the hypothesis that an enhanced cholinergic activity in vitiliginous skin may be a direct effect of increased local ACh concentration due to either increased secretion of decreased local clearing of ACh [54]. The hypothesis about causative role for ACh in depigmentation in vitiligo was formulated based on finding in the vitiliginous areas of an increase of a) surface temperature, b) sweat production, and 3) bleeding, which was interpreted as an evidence in favor of a local predominance of cholinergic influences, compared to the normal skin areas. Only very recently has it been recognized that AChE activity, but not that of ChAT, is regulated by $\mathrm{H}_{2} \mathrm{O}_{2}$ [55]. Considering that the outer layer of human skin can be a target for UV-generated $\mathrm{H}_{2} \mathrm{O}_{2}$ in the millimolar range, this mechanism needs to be taken into account for the regulation of $\mathrm{ACh}$ 
Hypothetical Role of ACh in Cutaneous Pigmentation and Photosensitivity

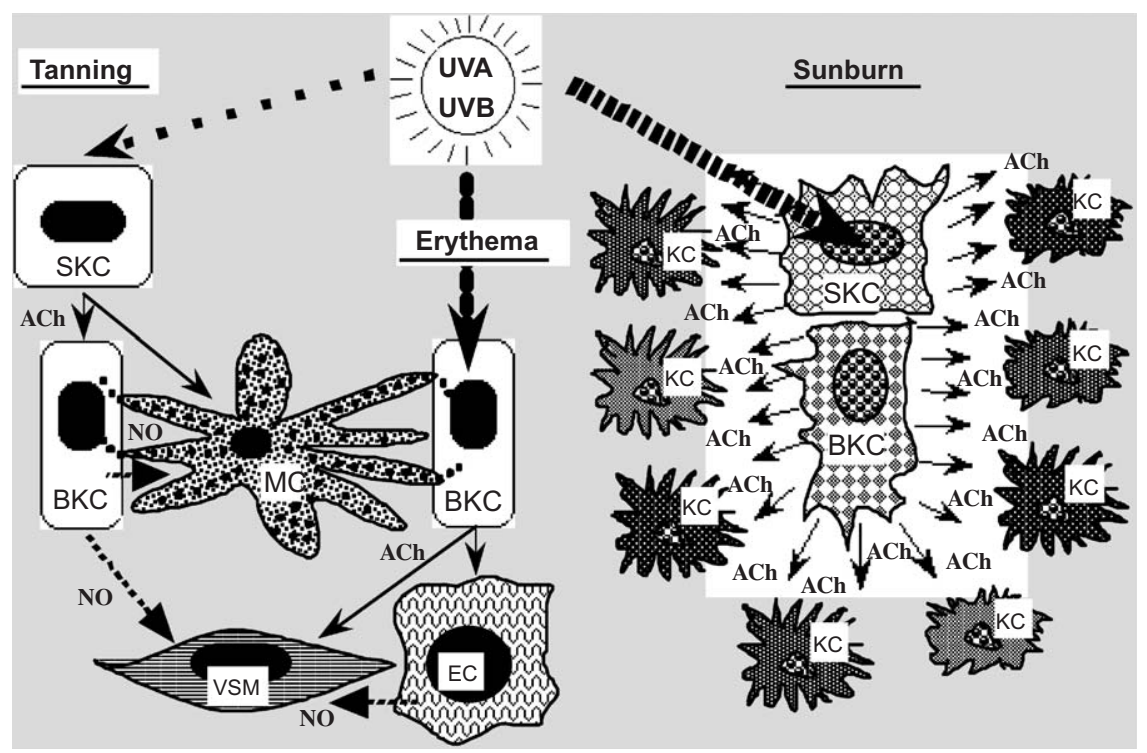

Fig. 1 Hypothetical scheme of ACh involvement in cutaneous UVR effects. The epidermis converts UVR into ACh signals by changing the kinetics of ACh metabolism in keratinocytes. Newly synthesized ACh then activates other skin cells by releasing NO. The cutaneous response involves melanocytes (MC), endothelial cells (EC), and vascular smooth muscles (VSM). The tanning UVR dose releases preformed ACh from suprabasal keratinocytes (SKC) which stimulates NO release from basal keratinocytes (BKC), thus activating melanogenesis and causing erythema. The inhibitory nature of delayed effects of ACh on MC [53] may be required to prevent hyperpigmentation. The erythemagenic dose stimulates BKC to release ACh. In addition to its putative immediate effect on MC, such as pigment aggregation, ACh, released by BKC, also stimulates NO production by EC, leading to erythema and increased microcirculatory flow [124]. The burning dose exhausts ACh stores and abolishes ACh signaling because it causes ACh receptor desensitization. Keratinocytes deprived of endogenous ACh shrink, loosen their attachments and thus die (a mechanism for blistering?). homeostasis in skin biology and pathology. In this context, it has been suggested that $\mathrm{ACh}$, as well as millimolar concentrations of $\mathrm{H}_{2} \mathrm{O}_{2}$, may well account for the described pruritus in active/ progressive vitiligo [4].

\section{The cholinergic system of dermal fibroblasts: regulation of cell-cycle progression and apoptosis}

High AChE activity in human dermis [56] suggested the existence of a non-neuronal cholinergic system in dermal fibroblasts (DFs). The results of RT-PCR, western blotting and immunofluorescence assays showed that human DFs respond to ACh via classical ACh receptors. At different in vitro and in vivo conditions, DFs may express $\alpha 3 \beta 2(\beta 4) \pm \alpha 5, \alpha 7$, and $\alpha 9$ nAChRs [20], and $\mathrm{M}_{2}, \mathrm{M}_{4}$, and $\mathrm{M}_{5} \mathrm{mAChR}$ subtypes coupled to the regulation of $\left[\mathrm{Ca}^{2+}\right]_{i}$ levels [57]. These findings are consistent with early reports that both anti-mAChR antibody $[18,58]$ and muscarinic drugs [59] react specifically with DFs.

Nicotinic and muscarinic effects on fibroblast proliferation had also been reported $[60,61]$. To elucidate the biological functions of nAChRs expressed in DFs, the nicotinic effects on transcription and translation of the genes encoding the cell cycle and apoptosis regulators were measured in in vitro experiments [62]. DFs stimulated with nicotine showed increased levels of the p21, cyclin D1, PCNA, Ki-67, caspase 3 and bcl-2 mRNA transcripts. These effects were largely blocked in the presence of mecamylamine - an antagonist preferentially ligating the "ganglionic" type of nAChRs. These results suggested that the role of the ACh-gated ion channels involves the contribution of the $\alpha 3$ subunit, i.e., $\alpha 3 \beta 2(\beta 4) \pm \alpha 5$, in the nicotinergic control of DFs.

Quantitative RT-PCR and western blotting assays were used to measure alterations in the expression of genes coding for the cell cycle and apoptosis markers in DFs from neonates delivered by $\alpha 3+/-$ mice [62]. Compared to wild type DFs, the $\alpha 3-/-$ DFs showed decreased mRNA levels of p21, PCNA, cyclin D1, Ki-67 and bcl-2, and increased mRNA levels of p53, bax and caspase 3 . Functional deletion of $\alpha 3 \mathrm{nAChR}$ with receptor-specific antisense oligonucleotides resulted in characteristic changes in the cell cycle gene expression, which were similar to those observed in DFs from $\alpha 3$ knockout mice. The changes in the cell cycle progression of murine DFs lacking $\alpha 3$ were found to be just the opposite to those observed in human DFs treated with nicotine, suggesting that DF $\alpha 3$-containing nAChRs mediate, at least in part, the effects of nicotine on DFs.

\section{Fibroblast nicotinic receptors control tissue remodeling \\ $\nabla$}

Nicotine has been reported to alter extracellular matrix reorganizational properties of DFs [63]. To determine the role of fibroblast nAChRs in mediating cutaneous effects of nicotine, the expression of collagen I $\alpha 1$, elastin and MMP- 1 were measured in cultured human and murine DFs [62]. Nicotine increased all studied parameters, and mecamylamine abolished these alterations, indicating that they resulted from stimulation of an $\alpha 3^{*}$-made $n A C h R$. A quantitative analysis of collagen $\mathrm{I} \alpha 1$, elastin and MMP-1 in DFs grown from $\alpha 3-/-$ mice showed a 1.3 -fold decrease of both the mRNA and the protein levels of elastin, compared to $\alpha 3+/+$ DFs. The mRNA level of collagen I $\alpha 1$ was not altered in $\alpha 3-/-$ DFs. Surprisingly, the mRNA and protein levels of MMP- 1 and the protein level of collagen $\mathrm{I} \alpha 1$ were increased in a3-/ - DFs, with MMP-1 mRNA exceeding the control level by 24-fold [62]. Thus, nicotine may alter elastin production through the signaling pathways downstream from $\alpha 3^{*} \mathrm{nAChR}$, whereas changes in the collagen $\alpha 1$ and MMP- 1 gene expression may be mediated by other type(s) of nAChRs expressed in DFs. In support of this concept, mRNA transcripts of collagen $\mathrm{I} \alpha 1$, elastin and MMP-1 are decreased in the skin of $\alpha 7$ knockout mice [64].

\section{Cutaneous toxicity of nicotine $\nabla$}

Epidemiological studies point to a significant correlation between tobacco smoke and alterations in tissue remodeling, 
such as premature skin aging, i. e., thin, dry, pale, rough and wrinkled, or simply "cigarette," skin [65]. Tobacco smoke contains at least 4000 chemicals, and it has been proposed that nicotine is one of the key constituents causing adverse health effects (reviewed in [66]). Smoking down-regulates collagen synthesis in skin, which is considered as one etiologic factor for accelerated skin aging [67]. The mechanism may involve upregulated expression of MMP-1, MMP-2 and MMP-3 [68]. The in vitro exposure experiments have demonstrated that nicotine significantly increases both degradation of type I collagen and collagen production $[63,69]$. The expression of the tissue inhibitor of MMP-1 and -3 mRNAs remained unchanged [70].

Recently it has been demonstrated that nAChRs expressed by non-neuronal cells not only mediate pharmacological effects of nicotine in these locations but also are a target themselves for deleterious effects of nicotine $[71,72]$. Long-term exposure to nicotine alters gene expression of nAChR subunits, which modifies nicotinic pharmacology of the exposed cells. Thus, for example an overexposure to nicotine alters both the ligand-binding kinetics and the subunit composition of nAChRs [62]. The changes in the $\alpha 3 \alpha 5 \alpha 7 \beta 2$ and $\beta 4 \mathrm{nAChR}$ subunit gene expression are found at both the mRNA and protein levels. Since exposure to nicotine increases the filaggrin content in keratinocytes [73], and since overstimulation of nAChRs produces antagonist-like effects due to receptor desensitization [71], the exhaustion of the nAChR-mediated regulatory pathway of moisturizing factor production may offer a novel explanation of the early appearance of premature aged skin in tobacco users [74]. Thus, some of the pathobiologic effects of tobacco products on extracellular matrix turnover in the skin may stem from nicotine-induced alterations in the physiologic control of the genetically determined program of growth and tissue remodeling in the dermis as well as alterations in the structure and function of fibroblast nAChRs.

\section{The role of the cholinergic system in endothelial cell biology and angiogenesis}

All four components of the non-neuronal cholinergic system are expressed within the endothelium, a tissue which is present ubiquitously in the body including skin. 1) Synthesis of ACh has been shown in cultured endothelial cells of different species including man [75-77]. Positive ChAT-immunohistochemistry and ChAT-mRNA were found in freshly isolated human umbilical cells $[78,79]$. 2) Positive immunohistochemistry of the catabolizing enzyme acetylcholinesterase has been demonstrated in brain capillaries [80]. 3) The high affinity choline uptake system supplies the endothelial cell with extracellular choline [81]. 4) Finally, muscarinic and nicotine receptors have been demonstrated on endothelial cells. $\mathrm{M}_{1}$ - and $\mathrm{M}_{3}-\mathrm{mAChR}$ are found in most vessels while only the mRNA transcript of the $\mathrm{M}_{2}$-subtype has been demonstrated in endothelial cells. In the pulmonary circulation it is also likely that the functionally active $\mathrm{M}_{4}$-subtype is expressed. Nicotine receptor subunits are expressed in a species- and tissue specific-manner: $\alpha 3, \alpha 5, \beta 2$ and $\beta 4$ subunits in endothelial cells of the human aorta [82]; $\alpha 3, \alpha 4, \alpha 5, \alpha 6, \alpha 7$, and $\alpha 10$ in rat aorta and $\alpha 2$ in rat pulmonary trunk [83]; $\alpha 3, \alpha 5$, $\alpha 7, \beta 2$ and $(\beta 4)$ subunits in bovine brain and rat coronary microvascular endothelial cells [84-86]. These subunits form functionally active homo- or heteropentamers. Taken together, endothelial cells represent a prominent part of the non-neuro- nal cholinergic system. Thus, these cells synthesize and may release non-neuronal $\mathrm{ACh}$, which by stimulating muscarinic and nicotinic receptors affects endothelial phenotypic functions, such as regulation of vasomotor tone, angiogenesis, infection and immune response.

Endogenous ACh may be involved in the regulation of these phenotypic functions by auto- and paracrine mechanisms. Importantly, applied cholinergic agonists/antagonists can interfere with this system including drugs applied directly on the skin (for example nicotine or scopolamine containing delivery systems). It is widely accepted that endothelial cells contribute to the regulation of perfusion. In vascular tissue acetylcholine via activation of muscarinic receptors ( $\mathrm{M}_{3}$ - and $\mathrm{M}_{1}$-subtypes) is a well-known mediator for the release of nitric oxide, endothelium-derived hyperpolarizing factor and prostanoids. Blood flow, shear stress and local blood pressure may affect endothelial ACh synthesis and release and as a consequence may modulate the release of vasoactive mediators. Milner and colleagues [87] have shown the release of endothelial ACh in response to an increased flow. The endothelium is also an important target for immuno-competent cells, which must penetrate the vascular wall to migrate into the tissue. Adhesion molecules mediate the cross talk between immune and endothelial cells. Kirkpatrick et al. [79] did not find an effect of nicotine (100 nM-100 $\mu \mathrm{M})$ on the expression of VCAM and E-selectin, but ICAM1 expression was slightly enhanced. In contrast to these results it was reported that nicotine substantially stimulated the expression of VCAM1, ICAM and E-selectin in human umbilical vein endothelial cells (HUVEC) via calcium influx, an effect blockable by mecamylamine and MAPK inhibitors [88-90]. It should also be considered that Saeed and colleagues described an inhibitory effect of nicotine on the expression of adhesion molecules, when the endothelium was stimulated by the Schwarztman reaction in vivo or by TNF $\alpha$ in vitro [91]. Probably, the effect of nicotine depends on the activation state of the endothelial cells.

Low concentrations of nicotine $(0.1 \mu \mathrm{M})$ promote the invasion of E. coli. bacteria in HUVEC, an effect which could be blocked by $\alpha$-bungarotoxin [92]. Whether this mechanism can explain the increased microbial infections of heavy smokers remains an open question. Nevertheless, it has convincingly demonstrated that nicotine impairs microvascular permeability: Nicotine increases the blood brain barrier permeability and paracellular permeability and reduces connexin 43 expression and gap-junctional communication $[84,86,93]$. All these findings open new and highly important insights into the fine tuning of endothelial homeostasis by non-neuronal cholinergic mechanisms. Nicotine promotes angiogenesis in vivo $(0.03 \mu \mathrm{g} / \mathrm{kg})$ and in vitro $(100 \mathrm{pM})$ in a mouse model and accelerates the growth of tumours under the condition of an artificially stimulated neovascularization [94]. In the in vitro model stimulated angiogenesis was blocked by mecamylamine or $\alpha$-bungarotoxin, indicating firstly that an endogenous cholinergic pathway is involved and secondly, that nicotinic receptors of the $\alpha 7$-subtype are mediating this effect [95]. Most likely, the proliferative effect of non-neuronal acetylcholine (or applied nicotine) contributes to this mechanism [96]. Such a mechanism may contribute to regeneration and repair of human tissue. However, an overstimulated or impaired nonneuronal cholinergic system may cause a reduction of the endothelial barrier function, an enhanced permeability for signaling molecules and migrating immune cells and as a consequence inflammation and imbalance between proliferation and cell death. 
Taken together, the endothelium can regulate its phenotypic functions via the involvement of the non-neuronal cholinergic system, i.e. is independent of cholinergic neurons. Non-neuronal ACh can originate from endothelial as well as from circulating immune cells. Smoking and other pathogenic (exogenous, endogenous) factors target the endothelial non-neuronal cholinergic system which contributes to the pathogenesis of various diseases like atherosclerosis, tumor growth and inflammation.

\section{Cholinergic components expressed in immune cells \\ $\nabla$}

Direct measurement of physiologically relevant amounts of ACh in the plasma and blood cells of humans and rabbits (see the review by Kawashima and Fujii [97] and Kawashima et al. [7]) has stimulated investigation of the synthesis of non-neuronal ACh by immune competent cells. While the Langerhans cells residing in follicular and interfollicular epidermis were demonstrated to express AChE [98] accumulated evidence demonstrates that lymphocytes express most of the cholinergic components found in the cholinergic nervous system and is consistent with expression of a non-neuronal cholinergic system in immune cells. For example, T cells produce ACh, ChAT [99] and CHT1. Both T and B cells express AChE and varying levels of mAChRs $\left(M_{1}, M_{2}, M_{3}, M_{4}\right.$ and $\left.M_{5}\right)$ and nAChRs $(\alpha 2, \alpha 3, \alpha 4, \alpha 5, \alpha 6$, $\alpha 7, \alpha 9, \alpha 10, \beta 2$ and $\beta 4$ ) (reviewed in Kawashima and Fujii [100]).

\section{Regulatory mechanisms affecting lymphocytic cholinergic activity \\ $\nabla$}

The $T$ cell activator phytohemagglutinin (PHA) up-regulates ChAT gene expression and enhances synthesis and release of ACh via TCR/CD3 complex activation [101]. Although in the periphery ACh synthesis is catalyzed by both ChAT and carnitine acetyltransferase [102], PHA specifically activates ChAT [101] and $\mathrm{M}_{5} \mathrm{mAChR}$ gene expression [103] in T cells. Similarly, monoclonal antibody-mediated stimulation of CD11a (LFA-1 $\alpha$-chain) up-regulates ChAT and $\mathrm{M}_{5} \mathrm{mAChR}$ gene expression in CEM T cells [104]. Lymphocytic cholinergic transmission appears to be activated by the interaction of $\mathrm{T}$ cells with antigen presenting cells and/or other cell types. Thus, for instance, immunological synapses are formed via the interaction of CD4 and CD8 with MHC class II and MHC class I, respectively, and between LFA-1 and ICAM-1 [100].

Staphylococcus aureus Cowan I up-regulates expression of $\mathrm{M}_{5} \mathrm{mAChR}$ mRNA in Daudi B cells and up-regulates expression of ChAT in mononuclear leukocytes (MNLs), thereby increasing their ACh content [103]. Thus, cytokines released from activated $B$ cells appear to act in an autocrine/paracrine fashion to stimulate ChAT expression and ACh synthesis by $\mathrm{T}$ cells, which in turn activates lymphocytic cholinergic transmission via $\mathrm{M}_{5} \mathrm{mAChRs}$ in both $\mathrm{T}$ and $\mathrm{B}$ cells.

\section{Roles of ACh in the regulation of lymphocyte function}

The biochemical and functional changes induced by stimulation of lymphocytic mAChRs and/or nAChRs include enhanced cytotoxic activity, increased cGMP and inositol-1,4,5-triphosphate
$\left(\mathrm{IP}_{3}\right)$ content, inhibition of cAMP synthesis and increased intracellular free $\mathrm{Ca}^{2+}$ concentration $\left(\left[\mathrm{Ca}^{2+}\right]_{\mathrm{i}}\right)$. ACh and mAChR agonists induce rapid increases in $\left[\mathrm{Ca}^{2+}\right]_{i}$ followed by $\mathrm{Ca}^{2+}$ oscillations in both CEM T cells and Daudi B cells $[97,100,105-$ 108]. RT-PCR analysis showed that $M A C h R$ agonists also up-regulate $c$-fos expression in both CEM and Daudi cells. Pharmacological analysis using various $\mathrm{MAChR}$-specific antagonists revealed that ACh induces $\mathrm{Ca}^{2+}$ signalling in lymphocytes via $\mathrm{M}_{3}$ and/or $\mathrm{M}_{5} \mathrm{mAChRs}$, leading to $\mathrm{IP}_{3}$-mediated up-regulation of $c$-fos expression, and that $\mathrm{M}_{1} \mathrm{mAChRs}$ are involved in the differentiation of CD8 + T cells into cytotoxic T cells [109]. Nicotinic cholinergic signaling also appears to be involved in the regulation of lymphocyte function. In human MNLs and leukemic $T$ and $B$ cell lines, nicotine acutely elicits influxes of extracellular $\mathrm{Ca}^{2+}$ that mediate rapid and transient increases of $\left[\mathrm{Ca}^{2+}\right]_{\mathrm{i}}$. That this response is effectively suppressed by $\alpha$-bungarotoxin in CEM cells indicates the nicotinic signal is transduced via $\alpha 7$ nAChRs [100,108]. In addition, chronic nicotine modifies immune function by inhibiting proliferative responses or by causing anergy via constitutive activation of protein kinases and depletion of $\mathrm{IP}_{3}$-sensitive $\mathrm{Ca}^{2+}$ stores. Finally, the altered lymphocytic cholinergic activity seen in animal models exhibiting immunological abnormalities is consistent with the involvement of a local lymphocytic cholinergic system in the regulation of immune function (reviewed in Kawashima and Fujii [100]).

\section{Possible interaction of immune cells with vascular endothelial cells (VECs) and keratinocytes (KCs) through non-neuronal ACh \\ $\checkmark$}

ACh may play an intermediary role in the dialogue between immune competent and tissue cells regulating immune function and local circulation [100]. During CAM-mediated interactions, $\mathrm{T}$ cells and VECs are believed to use ACh to communicate reciprocally via mAChRs on both cell types, and possibly nAChRs on $\mathrm{T}$ cells. Kawashima and Fujii proposed that the interactions between $\mathrm{T}$ cells and VECs facilitate ACh synthesis and release in both cell types, leading to vascular smooth muscle relaxation and erythema. Potentiation of NO synthesis during the interaction is believed to evoke local vascular smooth muscle relaxation, thereby facilitating extravascular migration of T cells. ACh released from T cells, and possibly VECs, may also be involved in regulating production of TNF- $\alpha$, which in turn acts on nAChRs in T cells (reviewed by Kawashima and Fujii [100]).

In addition to synthesizing $\mathrm{ACh}$ and expressing $\mathrm{mAChRs}$ and nAChRs [1], KCs have the ability to secrete cytokines and chemokines that facilitate lymphocyte recruitment to the skin. Furthermore, KCs also express MHC class II and adhesion molecules (ICAM-1) under the influence of lymphocyte-derived cytokines such as IFN- $\gamma$ and IL-17 [110]. Immunological synapses formed between $\mathrm{T}$ cells and $\mathrm{KC}$ s through the interaction of CD4 with MHC class II and LFA- 1 with ICAM- 1 should facilitate synthesis and release of ACh in both T cells and KCs, which should in turn act as an autocrine/paracrine factor on their own mAChRs and/or nAChRs, leading to skin lesions through modification of KC differentiation, cell cycle progression, adhesion and apoptosis (० Fig. 2). 


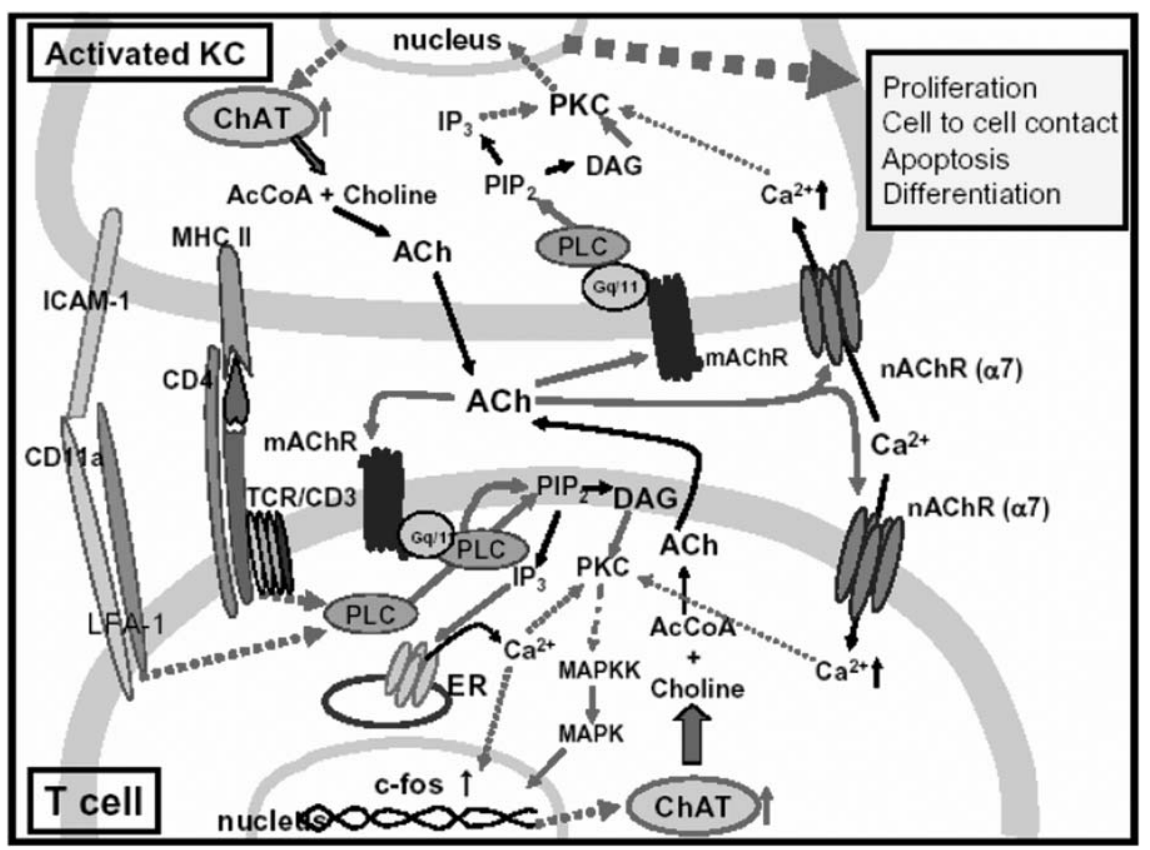

Fig. 2 Schematic diagram illustrating the numerous transduction and regulatory pathways that affect and are affected by the lymphocytic cholinergic system during the interaction of T cells with activated keratinocytes expressing $\mathrm{MHC}$ class II and ICAM-1. ACh: acetylcholine; AcCoA: acetyl coenzyme A; ChAT: choline acetyltransferase; DAG: diacyl glycerol; ER: endoplasmic reticulum; ICAM1: intercellular adhesion molecule-1; $\mathrm{IP}_{3}$ : inositol1,4,5-trisphosphate; KCs: keratinocytes; mAChR: muscarinic ACh receptor; MAPK: mitogen activated protein kinase; MAPKK: MAPK kinase; MHC: major histocompatibility complex; nAChR: nicotinic ACh receptor; PKC: protein kinase C; PIP2: phosphatidyl inositol-4,5-diphosphate; PLC: phospholipase C; TCR: T cell receptor.

\section{Cholinergic modulation of immune responses $\nabla$}

In addition to the mostly sympathetic hard-wiring of lymphatic organs by the autonomic nervous system $[111,112]$, which is a prerequisite for a direct activation of, e. g., lymphocytes in lymph nodes, extraneuronal "neurotransmitter" and local hormone systems have been recognized in recent years. A central player in this "inflammatory reflex" is the cholinergic system [113]. The autonomic cholinergic system, in part represented by the vagal nerve, transmits information bidirectionally from the peripheral immune organs to the brain and back, thus detecting local inflammatory reactions, e.g., in response to microbial invasion. This sensory input has been called the sixth sense. Consequently, dissecting the vagal nerve has serious consequences e.g. for the detection of bacterial infections. Intraperitoneal injection of Il-1 or endotoxin fails to induce fever after vagotomy. In contrast, electrical stimulation of the vagal nerve inhibits TNF- $\alpha$ production in the liver, spleen and heart observed during ischemia, shock or endotoxinemia. Many other in vitro data support a potent immune-modulating capacity of ACh. In macrophages, the inhibitory effect on TNF- $\alpha$, Il-1 or Il- 6 production seems to be mediated, at least in part, through the $\alpha 7 \mathrm{nACh}-\mathrm{R}$. The role of other AChR present on macrophages is still under investigation. In human alveolar macrophages, ACh has been found to stimulate chemotactic activity on neutrophils, monocytes and eosinophils. This chemotactic effect has been suggested to be predominantly mediated by leukotriene B4 [114]. A combination of different anticholinergic substances (4-DAMP effective, pirenzipine ineffective) that were able to inhibit the observed ACh effects, led the authors to conclude that the responsible AChR expressed on alveolar macrophages could be the $M_{3} m A C h R$. However, recent studies demonstrated that 4-DAMP does not discriminate between $\mathrm{M}_{3}$ and $\mathrm{M}_{5} \mathrm{AChR}$. In our own studies, we found $\mathrm{M}_{5}$ to be the predominant $\mathrm{mAChR}$ on human bloodderived macrophages (HK, unpublished observation).

Many anticholinergic substances such as ipratropium or tiotropium, currently in clinical use for the treatment of chronic obstructive pulmonary disease (COPD), have been shown to exert anti-inflammatory effects, supposedly through inhibition of the mAChR subunits on alveolar macrophages [115].

Nicotine has been shown to reduce IL- 2 and TNF- $\alpha$ release from PBMC significantly but not quite as potently as prednisolone. In addition, transdermal application of nicotine reduces the irritant contact eczema induced by SDS and similarly the UVBinduced sunburn reaction (reviewed in [4]). These nicotine effects may in part be explained by its ability to suppress the migration of leukocytes to an inflammation/infection site. The decreased inflammation correlates with lower chemotaxis/ chemokinesis of peripheral blood mononuclear cells (PBMC) toward formyl-methionyl-leucyl-phenylalanine and monocyte chemoattractant protein-1 without affecting the density of their respective receptors. Thus, because nicotine suppresses leukocyte migration, it might contribute to the delayed wound healing and increased incidence of respiratory infections among smokers [116]. Another potential disease-modulating effect was found in Chlamydia pneumoniae (Cpn)-infected immune cells. Lymphocytes and macrophages are susceptible to Cpn infection, which has been shown to alter their expression levels of IL-10, IL-12 and TNF- $\alpha$ in a time-dependent fashion. Nicotine treatment of the Cpn-infected cells up-regulated IL-10, but not TNFalpha and IL-12, and also resulted in significant down-regulation of TGF- $\beta 1$ production which was marked in the Cpn-infected control cells. The combined action of nicotine and Cpn on cytokine production may have an impact in chronic inflammatory diseases [117].

\section{Interaction of systems \\ $\nabla$}

It is well known that the release of ACh from cholinergic neurons is modulated by a battery of receptors located on the varicosities. For example, noradrenaline inhibits the release of ACh from myenteric neurons via $\alpha 2$-adrenoceptors and vice versa acetylcholine reduces the release of noradrenaline via presynap- 
tic inhibitory muscarinic receptors. In addition various kinds of neuronally localized receptors (adenosine receptors, 5-hydroxytryptamine receptors, opioid receptors, P2X- and P2Y-receptors, prostanoid receptors) modulate the release of neuronal ACh. It is unknown, whether the release of non-neuronal ACh is regulated likewise. In the human placenta the release of nonneuronal ACh is stimulated by nicotine receptors. Moreover, in the human placenta it has been shown that the release of nonneuronal acetylcholine is mediated via organic cation transporters, subtype OCT1 and ОСТ3, the latter also known as non-neuronal catecholamine uptake 2 [118]. The cation transporters are widely expressed and multiple interactions with endogenous substrates as well as with applied drugs are possible [119]. Thus multiple interactions between endogenous compounds as well as xenobiotics and the release of non-neuronal acetylcholine can emerge. For example, noradrenaline and adrenaline reduced the release of non-neuronal ACh in the human placenta via substrate inhibition at the cation transporter. Thus, circulating catecholamines may interfere with the release of non-neuronal acetylcholine at this common target via substrate competition, i.e., on the basis of a receptor-independent pathway. Quinine, like many as drugs, is a strong inhibitor of OCTs and reduces the release of non-neuronal acetylcholine which may explain its atropine-like actions [120]. For further research it is important to identify those drugs which interfere with the release of non-neuronal acetylcholine in attempt to find new therapeutical targets and to reduce possible side effects of the current therapy.

It is also possible that non-neuronal ACh released from epithelial cells modifies the functions of immune cells migrating into the mucosa and vice versa. The action radius of non-neuronal ACh is not known. Can ACh released from fibroblasts, fat cells or eccrine glands within the skin cross the basal membrane and attain at all epidermal cell layers? We assume a very restricted area of action, because of the ubiquitously expressed esterases. The ACh specific esterase represents the most effective enzyme created by nature so far. In vascular tissue, however, it is possible that non-neuronal ACh released from adherent immune cells interacts with endothelial cells. Also within the microvascular space (lung, intestine) a direct interaction between endothelial and epithelial acetylcholine appears possible.

\section{Perspective}

$\nabla$

In the last 10-15 year, a wealth of data has emerged, describing different roles of extra- or non-neuronal ACh in different organs, most notably a highly complex setting of active players and targets and possible bystanders in the cholinergic concert. In the skin, not only epidermal keratinocytes are the main players, but in addition, as described, most other components permanently or transiently residing in the skin. Whether it is mostly autocrine and paracrine or also endocrine actions of $\mathrm{ACh} /$ choline and the AChRs which predominate in different pathobiological scenarios still remains to be elucidated. Bridges will have to be built to the autonomic cholinergic system and most importantly to the different components of the immune system.

\footnotetext{
References

1 Grando SA: Biological functions of keratinocyte cholinergic receptors. J Invest Dermatol Symp Proc 1997; 2: 41-48
}

2 Zouboulis CC: Human skin: an independent peripheral endocrine organ. Horm Res 2000; 54: 230-242

3 Schallreuter KU: Epidermal adrenergic signal transduction as part of the neuronal network in the human epidermis. J Investig Dermatol Symp Proc 1997; 2: 37-40

4 Kurzen $\mathrm{H}$, Schallreuter $\mathrm{KU}$ : Novel aspects in cutaneous biology of acetylcholine synthesis and acetylcholine receptors. Exp Dermatol 2004; 13 (Suppl 4): 27-30

5 Conti-Tronconi BM, McLane KE, Raftery MA, Grando SA, Protti MP: The nicotinic acetylcholine receptor: structure and autoimmune pathology. Crit Rev Biochem Mol Biol 1994; 29: 69-123

6 Mark MR, Domino EF, Han SS, Ortiz A, Mathews BN, Tait SK: Effect of parasympathetic denervation on acetylcholine levels in the rat parotid gland. Is there an extraneuronal pool of acetylcholine? Life Sci 1983; 33: 1191-1197

7 Kawashima K, Oohata H, Suzuki T, Fujimoto K: Extraneuronal localization of acetylcholine and its release upon nicotine stimulation. Neurosci Lett 1989; 104: 336-339

8 Horiuchi Y, Kimura R, Kato N, Fujii T, Seki M, Endo T, Kato T, Kawashima K: Evolutional study on acetylcholine expression. Life Sci 2003; 72: $1745-1756$

9 Kurzen H, Berger H, Jäger C, Hartschuh W, Näher H, Gratchev A, Goerdt $S$, Deichmann M: Phenotypical and molecular profiling of the extraneuronal cholinergic system of the skin. J Invest Dermatol 2004; 123: 937-949

10 Wessler I, Kilbinger H, Bittinger F, Unger R, Kirkpatrick CJ: The nonneuronal cholinergic system in humans: expression, function and pathophysiology. Life Sci 2003; 72: 2055-2061

11 van Koppen CJ, Kaiser B: Regulation of muscarinic acetylcholine receptor signaling. Pharmacol Ther 2003; 98: 197-220

12 Millar N: Assembly and subunit diversity of nicotinic acetylcholine receptors. Biochem Soc Trans 2003; 31: 869-874

13 Sgard F, Charpentier E, Bertrand S, Walker N, Caput D, Graham D, Bertrand D, Besnard F: A novel human nicotinic receptor subunit, $\alpha 10$, that confers functionality to the $\alpha 9$-subunit. Mol Pharmacol 2001; 61: 150-159

14 Shi H, Wang H, Lu Y, Yang B, Wang Z: Choline modulates cardiac membrane repolarization by activating an M3 muscarinic receptor and its coupled $\mathrm{K}^{+}$channel. J Membr Biol 1999; 169: 55-64

15 Zwart R, Vijverberg HP: Potentiation and inhibition of neuronal nicotinic receptors by atropine: competitive and noncompetitive effects. Mol Pharmacol 1997; 52: 886-895

16 Parker JC, Sarkar D, Quick MW, Lester RA: Interactions of atropine with heterologously expressed and native alpha 3 subunit-containing nicotinic acetylcholine receptors. $\mathrm{Br} \mathrm{J}$ Pharmacol 2003; 138: 801-810

17 Elgoyhen $A B$, Johnson $D$, Boulter J, Vetter DE, Heinemann $S$ : $\alpha 9$ : an acetylcholine receptor with novel pharmacological properties expressed in rat cochlear hair cells. Cell 1994; 79: 705-715

18 Grando SA, Zelickson BD, Kist DA, Weinshenker D, Bigliardi PL, Wendelschafer-Crabb G, Kennedy WR, Dahl MV: Keratinocyte muscarinic acetylcholine receptors: immunolocalization and partial characterization. J Invest Dermatol 1995; 104: 95-100

19 Verbitsky M, Rothlin $C V$, Katz E, Elgoyhen $A B$ : Mixed nicotinic-muscarinic properties of the alpha9 nicotinic cholinergic receptor. Neuropharmacology 2000; 39: 2515-2524

20 Arredondo J, Nguyen VT, Chernyavsky AI, Bercovich D, Orr-Urtreger A, Kummer W, Lips K, Vetter DE, Grando SA: Central role of alpha7 nicotinic receptor in differentiation of the stratified squamous epithelium. J Cell Biol 2002; 159: 325-336

21 Gharagozloo P, Lazareno S, Popham A, Birdsall NJ: Allosteric interactions of quaternary strychnine and brucine derivatives with muscarinic acetylcholine receptors. J Med Chem 1999; 42: 438-445

22 Jakublik J, Backova L, El-Fakahany EE, Tucek S: Positive cooperativity of acetylcholine and other agonists with allosteric ligands on muscarinic acetylcholine receptors. Mol Pharmacol 1997; 52: 172-179

23 Birdsall NJ, Farries T, Gharagozloo P, Kobayashi S, Lazareno S, Sugimoto M: Subtype-selective positive cooperative interactions between brucine analogs and acetylcholine at muscarinic receptors: functional studies. Mol Pharmacol 1999; 55: 778-786

24 Chernyavsky AI, Arredondo J, Marubio LM, Grando SA: Differential regulation of keratinocyte chemokinesis and chemotaxis through distinct nicotinic receptor subtypes. J Cell Sci 2004; 117: 5665-5679

25 Chernyavsky AI, Arredondo J, Karlsson E, Wessler I, Grando SA: The RAS/RAF-1/MEK1/ERK signaling pathway coupled to integrin expression mediates cholinergic regulation of keratinocyte directional migration. J Biol Chem 2005; 280: 39220-39228

26 Blusztajn JK: Choline, a vital amine. Science 1998; 281 (5378): 794-795 
27 Ilcol YO, Ozbek R, Hamurtekin E, Ulus IH: Choline status in newborns, infants, children, breast-feeding women, breast-fed infants and human breast milk. J Nutr Biochem 2005; 16: 489-499

28 Mohs RC, Davis KL: Choline chloride effects on memory: correlation with the effects of physostigmine. Psychiatry Res 1980; 2: 149-156

29 da Costa KA, Badea M, Fischer LM, Zeisel SH: Elevated serum creatine phosphokinase in choline-deficient humans: mechanistic studies in C2C12 mouse myoblasts. Am J Clin Nutr 2004; 80: 163-170

30 Holmes-McNary MQ Baldwin AS, Jr, Zeisel SH: Opposing regulation of choline deficiency-induced apoptosis by p53 and nuclear factor kappaB. J Biol Chem 2001; 276: 41197-41204

31 Danne O, Mockel M, Lueders C, Mugge C, Zschunke GA, Lufft H, Muller $C$, Frei $U$ : Prognostic implications of elevated whole blood choline levels in acute coronary syndromes. Am J Cardiol 2003; 91: 1060-1067

32 Grando SA, Kist DA, Qi M, Dahl MV: Human keratinocytes synthesize, secrete, and degrade acetylcholine. J Invest Dermatol 1993; 101: 32-36

33 Nguyen VT, Ndoye A, Hall LL, Zia S, Arredondo J, Chernyavsky AI, Kist $D A$, Zelickson BD, Lawry MA, Grando SA: Programmed cell death of keratinocytes culminates in apoptotic secretion of a humectant upon secretagogue action of acetylcholine. J Cell Sci 2001; 114: 1189-1204

34 Lips KS, Pfeil U, Kummer W: Coexpression of $\alpha 9$ and $\alpha 10$ nicotinic acetylcholine receptor subunits in rat dorsal root ganglion neurons. Neuroscience 2002; 115: 1-5

35 Elgoyhen $A B$, Vetter DE, Katz E, Rothlin CV, Heinemann SF, Boulter J: alpha10: a determinant of nicotinic cholinergic receptor function in mammalian vestibular and cochlear mechanosensory hair cells. Proc Natl Acad Sci USA 2001; 98: 3501-3506

36 Kurzen H, Berger H, Jager C, Hartschuh W, Maas-Szabowski N: Alpha 9 acetylcholine receptors are essential for epidermal differentiation. Exp Dermatol 2005; 14: 155

37 Gordon PR, Gelman LK, Gilchrest BA: Demonstration of a choline requirement for optimal keratinocyte growth in a defined culture medium. J Nutr 1988; 118: 1487-1494

38 Nguyen VT, Chernyavsky AI, Arredondo J et al: Synergistic control of keratinocyte adhesion through muscarinic and nicotinic acetylcholine receptor subtypes. Exp Cell Res 2004; 294: 534-549

39 Zouboulis CC, Boschnakow A: Chronological ageing and photoageing of the human sebaceous gland. Clin Exp Dermatol 2001; 26: 600-607

40 Schafer T, Nienhaus A, Vieluf D, Berger J, Ring J: Epidemiology of acne in the general population: the risk of smoking. Br J Dermatol 2001; 145: $100-104$

41 Tretyn A, Kendrick RE: Acetylcholine in plants presence metabolism and mechanism of action. Botan Rev 1991; 57: 33-73

42 Gupta R, Saxena RK, Goel S: Photoinduced sporulation in Trichoderma harzianum: an experimental approach to primary events. World J Microbiol Biotechnol 1997; 13: 249-250

43 Buchli R, Ndoye A, Arredondo J, Webber RJ, Grando SA: Identification and characterization of muscarinic acetylcholine receptor subtypes expressed in human skin melanocytes. Mol Cell Biochem 2001; 228: 57-72

44 Zhao H, Boissy RE, Nordlung JJ: Down-regulation of human melanogenesis by acetylcholine in culture. J Invest Dermatol 1996; 106: 910

45 Moller $H$, Lerner $A B$ : Melanocyte stimulating hormone inhibition by acetylcholine and noradrenaline in the frog skin bioassay. Acta Endocrinol 1966; 51: 149-160

46 Wallstrom M, Sand L, Nilsson F, Hirsch JM: The long-term effect of nicotine on the oral mucosa. Addiction 1999; 94: 417-423

47 Gillbro JM, Marles LK, Hibberts NA, Schallreuter KU: Autocrine catecholamine biosynthesis and the beta-adrenoceptor signal promote pigmentation in human epidermal melanocytes. J Invest Dermatol 2004; 123: 346-353

48 Warren JB: Nitric oxide and human skin blood flow responses to acetylcholine and ultraviolet light. FASEB J 1994; 8: 247-251

49 Lewis T, Harris KE, Grant RT: Observations relating to the influence of the cutaneous nerves on various reactions of the cutaneous vessels. Heart 1927; 14: 1-15

50 Kang-Rotondo CH, Major S, Chiang TM, Myers LK, Kang ES: Upregulation of nitric oxide synthase in cultured human keratinocytes after ultraviolet B and bradykinin. Photoderm Photoimmunol Photomed 1996; 12: 57-65

51 Romero-Graillet C, Aberdam E, Clement M, Ortonne JP, Ballotti R: Nitric oxide produced by ultraviolet-irradiated keratinocytes stimulates melanogenesis. J Clin Invest 1997; 99: 635-642

52 Sawada Y, Sakamaki T, Nakamura T, Sato K, Ono Z, Murata K: Release of nitric oxide in response to acetylcholine is unaltered in spontaneously hypertensive rats. J Hypertens $1994 ; 12$ : 745-750
53 Iyengar B: Modulation of melanocytic activity by acetylcholine. Acta Anat 1989; 136: 139-141

54 Chanco-Turner $M L$, Lerner AB: Physiologic changes in vitiligo. Arch Dermatol 1965; 91: 390-396

55 Schallreuter KU, Elwary SM, Gibbons NC, Rokos H, Wood JM: Activation/deactivation of acetylcholinesterase by $\mathrm{H}_{2} \mathrm{O}_{2}$ : more evidence for oxidative stress in vitiligo. Biochem Biophys Res Commun 2004; 315 : 502-508

56 Magnus IA, Thompson RHS: Cholinesterase activity of human skin. $\mathrm{Br}$ J Dermatol 1954; 66: 163-173

57 Buchli R, Ndoye A, Rodriguez JG, Zia S, Webber RJ, Grando SA: Human skin fibroblasts express $\mathrm{m} 2, \mathrm{~m} 4$, and $\mathrm{m} 5$ subtypes of muscarinic acetylcholine receptors. J Cell Biochem 1999; 74: 264-277

58 Raposo G, Dunia I, Marullo S, Andre C, Guillet JG, Strosberg AD, Benedetti EL, Hoebeke J: Redistribution of muscarinic acetylcholine receptors on human fibroblasts induced by regulatory ligands. Biology of the Cell 1987; 60: 117-123

59 Vestling M, Cowburn RF, Venizelos $N$, Lannfelt L, Winblad B, Adem A: Characterization of muscarinic acetylcholine receptors in cultured adult skin fibroblasts: effects of the Swedish Alzheimer's disease APP $670 / 671$ mutation on binding levels. J Neur Transm (Parkinson's Disease and Dementia Section) 1995; 10: 1-10

60 Chew SJ, Lopez JG, Wilson R, Beuerman RW: Muscarinic antagonists inhibit the proliferation and EGF receptor expression of human ocular and NIH-3T3 fibroblasts. Soc Neurosci Abstr 1992; 18: 927

61 Peacock ME, Sutherland DE, Schuster GS, Brennan WA, O'Neal RB, Strong SL, Van Dyke TE: The effect of nicotine on reproduction and attachment of human gingival fibroblasts in vitro. J Periodontol 1993; 64: 658-665

62 Arredondo J, Hall LH, Ndoye A, Nguyen VT, Chernyavsky AI, Bercovich $D$, Orr-Urtreger A, Beaudet AL, Grando SA: Central role of fibroblast $\alpha 3$ nicotinic acetylcholine receptor in mediating cutaneous effects of nicotine. Lab Invest 2003; 83: 207-225

63 Tipton DA, Dabbous MK: Effects of nicotine on proliferation and extracellular matrix production of human gingival fibroblasts in vitro. J Periodontol 1995; 66: 1056-1064

64 Arredondo J, Nguyen VT, Chernyavsky AI, Bercovich D, Orr-Urtreger A Vetter DE, Grando SA: Functional role of $\alpha 7$ nicotinic receptor in physiological control of cutaneous homeostasis. Life Sci 2003; 72 : 2063-2067

65 Frances C: Smoker's wrinkles: epidemiological and pathogenic considerations. Clin Dermatol 1998; 16: 565-570

66 Conti-Fine BM, Navaneetham D, Lei S, Maus AD: Neuronal nicotinic receptors in non-neuronal cells: new mediators of tobacco toxicity? Eur J Pharmacol 2000; 393: 279-294

67 Raitio A, Vahakangas K, Haapasaari K-M, Risteli J, Oikarinen A: Smoking downregulates collagen synthesis in skin. J Invest Dermatol 1999; 113: 452

68 Carty CS, Soloway PD, Kayastha S, Bauer J, Marsan B, Ricotta JJ, Dryjski $M$ : Nicotine and cotinine stimulate secretion of basic fibroblast growth factor and affect expression of matrix metalloproteinases in cultured human smooth muscle cells. J Vasc Surg 1996; 24: 27-35

69 Chamson A, Frey J, Hivert M: Effects of tobacco smoke extracts on collagen biosynthesis by fibroblast cell cultures. J Toxicol Environ Health 1982; 9: 921-932

70 Yin L, Morita A, Tsuji T: Alterations of extracellular matrix induced by tobacco smoke extract. Arch Dermatol Res 2000; 292: 188-194

71 Zia S, Ndoye A, Nguyen VT, Grando SA: Nicotine enhances expression of the $\alpha 3, \alpha 4, \alpha 5$, and $\alpha 7$ nicotinic receptors modulating calcium metabolism and regulating adhesion and motility of respiratory epithelial cells. Res Commun Mol Pathol Pharmacol 1997; 97: 243-262

72 Arredondo J, Nguyen VT, Chernyavsky AI, Jolkovsky DL, Pinkerton KE, Grando SA: A receptor-mediated mechanism of nicotine toxicity in oral keratinocytes. Lab Invest 2001; 81: 1653-1668

73 Grando SA, Horton RM, Mauro TM, Kist DA, Lee TX, Dahl MV: Activation of keratinocyte nicotinic cholinergic receptors stimulates calcium influx and enhances cell differentiation. J Invest Dermatol 1996; 107: 412-418

74 Smith JB, Fenske NA: Cutaneous manifestations and consequences of smoking. J Am Acad Dermatol 1996; 34: 717-732

75 Parnavelas JG, Kelly W, Burnstock G: Ultrastructural localization of choline acetyltransferase in vascular endothelial cells in rat brain. Nature 1985; 316: 724-725

76 Kawashima K, Watanabe N, Oohata H, Fujimoto K, Suzuki T, Ishizaki $Y$, Morita I, Murota S: Synthesis and release of acetylcholine by cultured bovine arterial endothelial cells. Neurosci Lett 1990; 119; 156-158 
77 Kirkpatrick CJ, Bittinger F, Unger RE, Kriegsmann J, Kilbinger H, Wessler I: The non-neuronal cholinergic system in the endothelium: evidence and possible pathobiological significance. Jap J Pharmacol 2001; 85: 24-28

78 Haberberger RV, Bodenbenner $M$, Kummer $W$ : Expression of the cholinergic gene locus in pulmonary arterial endothelial cells. Histochem Cell Biol 2000; 113: 379-387

79 Kirkpatrick CJ, Bittinger F, Nozadze K, Wessler I: Expression and function of the non-neuronal cholinergic system in endothelial cells. Life Sci 2003; 72: 211-216

80 Ciani F, Franceschini V: Ultrastructural study and cholinesterase activity of paired capillaries in the new brain. J Hirnforsch 1984; 25: 11-20

81 Lips KS, Pfeil U, Reiner K, Rimasch C, Kuchelmeister K, Braun-Dullaeus $R C$, Haberberger RV, Schmidt R, Kummer $W$ : Expression of the high affinity choline transporter CHT1 in rat and human arteries. J Histochem Cytochem 2003; 51: 1645-1654

82 Macklin KD, Maus AD, Pereira EF, Albuquerque EX, Conti-Fine BM: Human vascular endothelial cells express functional nicotinic acetylcholine receptors. J Pharmacol Exp Ther 1998; 287: 435-439

83 Brüggmann D, Lips KS, Pfeil U, Haberberger RV, Kummer W: Rat arteries contain multiple nicotine acetylcholine receptor $\alpha$-subunits. Life Sci 2003; 72: 2095-2099

84 Abbruscato TJ, Lopez SP, Marks KS, Hawkins BT, Davis TP: Nicotine and cotonine modulate cerebral microvascular permeabilità and protein expression of ZO-1 through nicotinic acetylcholine receptors expressed on brain endothelial cells. J Pharm Sci 2002; 91: 2525-2538

85 Moccia F, Frost C, Berra-Romani R, Tanzi F, Adams DJ: Expression and function of neuronal nicotinic receptors in rat microvascular endothelial cells. Am J Physiol Heart Circ Physiol 2004; 286: H486-H491

86 Hawkins BT, Egleton RD, Davis TP: Modulation of cerebral microvascular permeability by endothelial nicotinic acetylcholine receptors. Am J Physiol Heart Circ Physiol 2005; 289: H212-H219

87 Milner P, Kirkpatrick K, Ralevic V, Toothill V, Pearson J, Burnstock G: Endothelial cells cultured from umbilical vein release ATP, substance $\mathrm{P}$, and acetylcholine in response to increased flow. Proc R Soc Lond (Biol) 1990; 241: 245-248

88 Albough G, Bellavance E, Strande L, Heinburger S, Hewitt CW, Alexander JB: Nicotine induces mononuclear leukocyte adhesion and expression of adhesion molecules, VCAM and ICAM, in endothelial cells in vitro. Ann Vasc Surg 2004; 18: 302-307

89 Wang Y, Wang L, Ai X, Zhao J, Hao X, Lu Y, Qiao Z: Nicotine could augment adhesion molecule expression in human endothelial cells through macrophages secreting TNF $\alpha$, IL-1 $\beta$. Int Immunopharmacol. 2004; 4: 1675-1686

90 Wang Y, Wang Z, Zhou Y, Liu L, Zhao Y, Yao C, Wang L, Qiao Z: Nicotine stimulates adhesion molecular expression via calcium influx and mitogen-activated protein kinases in human endothelial cells. Int J Biochem Cell Biol. 2006; 38: 170-182

91 Saeed RW, Varma S, Peng-Nemeroff, Sherry B, Balakhaneh J, Tracey KJ, Al-Abed Y, Metz CN: Cholinergic stimulation blocks endothelial cell activation and leukocyte recruitment during inflammation. JEM 2005; 201: 1113-1123

92 Chen YH, Chen SHM, Jong A, Zhou ZY, Li W, Suzuki K, Huang SH: Enhanced Escherichia coli invasion of human brain microvascular endothelial cells is associated with alternations in cytoskeleton induced by nicotine. Cell Microbiol 2002; 4: 503-514

93 Tsai CH, Yeh HI, Tian TY, Lee YN, Lu CS, Ko YS: Down regulating effect of nicotine on connexin43 gap junctions in human umbilical vein endothelial cells is attenuated by statins. Eur J Cell Biol 2004; 82: 589-595

94 Heeschen C, Jang JJ, Weis M, Pathak A, Kaji S, Hu RS, Tsao PS, Johnson $F L$, Cooke JP: Nicotine stimulates angiogenesis and promotes tumor growth and atherosclerosis. Nature Med 2001; 7: 833-839

95 Heeschen $C$, Weis $M$, Aicher A, Dimmeler S, Cooke JP: A novel angiogenic pathway mediated by non-neuronal nicotinic acetylcholine receptors. J Clin Invest 2002; 110: 527-536

96 Villablanca AC: Nicotine stimulates DNS synthesis and proliferation in vascular endothelial cells in vitro. J Appl Physiol 1998; 84: 2089-2098

97 Kawashima K, Fujii T: Extraneuronal cholinergic system in lymphocytes. Pharmacol Ther 2000; 86: 29-48

98 Hollis DE, Lyne AG: Acetylcholinesterase-positive langerhans cells in the epidermis and wool follicles of the sheep. J Invest Dermatol 1972; 58: $211-217$

99 Fujii T, Yamada S, Misawa H, Tajima S, Fujimoto K, Suzuki T, Kawashima $K$ : Expression of choline acetyltransferase mRNA and protein in Tlymphocytes. Proc Japan Acad 1995; 71B: 231-235
100 Kawashima K, Fujii T: Expression of non-neuronal acetylcholine in lymphocytes and its contribution to the regulation of immune function. Front Biosci 2004; 9: 2063-2085

101 Fujii T, Tsuchiya T, Yamada S, Fujimoto K, Suzuki T, Kasahara T, Kawashima K: Localization and synthesis of acetylcholine in human leukemic T-cell lines. J Neurosci Res 1996; 44: 66-72

102 Tucek S: The synthesis of acetylcholine in skeletal muscles of the rat J Physiol (Lond) 1982; 322: 53-69

103 Fujii T, Watanabe Y, Inoue T, Kawashima K: Up-regulation of mRNA encoding the M5 muscarinic acetylcholine receptor in human T- and B-lymphocytes during immunological responses. Neurochem Res 2003; 28: 423-429

104 Fujii T, Ushiyama N, Hosonuma K, Suenaga A, Kawashima K: Effects of human antithymocyte globulin on acetylcholine synthesis, its release and choline acetyltransferase transcription in a human leukemic T-cell line. J Neuroimmunol 2002; 128: 1-8

105 Fujii T, Kawashima K: Calcium oscillation is induced by muscarinic acetylcholine receptor stimulation in human leukemic T- and B-cell lines. Naunyn-Schmiedberg's Arch Pharmacol 2000; 362: 14-21

106 Fuji T, Kawashima K: An independent non-neuronal cholinergic system in lymphocytes. Jpn J Pharmacol 2001; 85: 11-15

107 Kawashima K, Fujii T: Minireview: The lymphocytic cholinergic system and its contribution to the regulation of immune activity. Life Sci 2003; 74: 675-696

108 Kawashima K, Fuji T: The lymphocytic cholinergic system and its contribution to the regulation of immune activity. Life Sci 2003; 74 : 675-696

109 Zimring JC, Kapp LM, Yamada M, Wess J, Kapp JA: Regulation of CD8 cytotoxic T lymphocyte differentiation by a cholinergic pathway. J Immunol 2005; 164: 66-75

110 Albanesi C, Cavani A, Girolomoni G: Interferon- $\gamma$-stimulated human keratinocytes express the genes necessary for the production of peptide-loaded MHC-class II molecules. J Invest Dermatol 1998; 110: 138-142

111 Weihe E, Nohr D, Michel S, Muller S, Zentel HJ, Fink T, Krekel J: Molecular anatomy of the neuro-immune connection. Int J Neurosci 1991; 59: $1-23$

112 Tracey KJ: The inflammatory reflex. Nature 2002; 420 (6917): 853-859

113 Pavlov VA, Wang H, Czura CJ, Friedman SG, Tracey KJ: The cholinergic anti-inflammatory pathway: a missing link in neuroimmunomodulation. Mol Med 2003; 9: 125-134

114 Sato E, Koyama S, Okubo Y, Kubo K, Sekiguchi M: Acetylcholine stimulates alveolar macrophages to release inflammatory cell chemotactic activity. Am J Physiol 1998; 274: L970-L979

115 Disse B: Antimuscarinic treatment for lung diseases from research to clinical practice. Life Sci 2001; 68: 2557-2564

116 Razani-Boroujerdi S, Singh SP, Knall C, Hahn FF, Pena-Philippides JC, Kalra R, Langley RJ, Sopori ML: Chronic nicotine inhibits inflammation and promotes influenza infection. Cell Immunol. 2004; 230: 1-9

117 Mamata Y, Hakki A, Yamamoto Y, Newton C, Klein TW, Pross S, Friedman $H$ : Nicotine modulates cytokine production by Chlamydia pneumoniae infected human peripheral blood cells. Int Immunopharmacol 2005; 5: 749-756

118 Wessler I, Deutsch C, Brockerhoff P, Bittinger F, Kirkpatrick CJ, Kilbinger $H$ : Release of non-neuronal acetylcholine from the isolated human placenta is mediated by organic cation transporters. $\mathrm{Br} \mathrm{J}$ Pharmacol 2001; 134: 951-956

119 Koepsell H: Organic cation transporters in intestine, kidney, liver and brain. Annu Rev Physiol 1998; 60: 243-266

120 Wessler I, Deutsch C, Bittinger F, Kirkpatrick CJ, Kilbinger H: Catecholamines inhibit the release of non-neuronal acetylcholine by substrate inhibition at the organic cation transporters. Naunyn-Schmiedeberg's Arch Pharmacol 2002; 365 (Suppl): R22

121 Alexander SPH, Mathie A, Peters JA: Guide to Receptors and Channels: 7 TM Receptors. Br J Pharmacol 2005; 144: 4-62

122 Alexander SPH, Mathie A, Peters JA: Guide to receptors and channels: ion channels. Br J Pharmacol 2005; 144: 73-94

123 Haddad EB, Patel H, Keeling JE, Yacoub MH, Barnes PJ, Belvisi MG: Pharmacological characterization of the muscarinic receptor antagonist, glycopyrrolate, in human and guinea-pig airways. Br J Pharmacol 1999; 127: 413-420

124 Hayashi H, Fujii R: Pharmacological profiles of the subtypes of muscarinic cholinoceptors that mediate aggregation of pigment in the melanophores of two species of catfish. Pigm Cell Res 1994; 7: 175-183 